\title{
PERAN IRON OVERLOAD PADA PROSES INFLAMASI ENDOMETRIOSIS
}

\author{
Cicilia Febriani Hayuningrum ${ }^{1)^{*}}$; Yordan Khaedir ${ }^{2)}$ \\ 1) cicilia.hayuningrum@gmail.com, Program Studi DIII Fisioterapi Politeknik Kesehatan Hermina* \\ 2) khaedir@gmail.com, Program Magister Ilmu Biomedik Universitas Indonesia \\ *penulis korespondensi
}

\begin{abstract}
Endometriosis is a gynecological condition characterized by the implantation of endometrial tissue outside the uterine cavity. Endometriosis is characterized by the occurrence of a chronic inflammatory process in the peritoneal cavity, causes various symptoms. Many factors are involved in the chronic inflammatory process of endometriosis, oxidative stress is one key factors induced chronic inflammatory condition, which related with iron overload.
\end{abstract}

Keywords : endometriosis, chronic inflammation, oxidative stress, iron overload

\begin{abstract}
Abstrak
Endometriosis merupakan kondisi ginekologikal yang ditandai dengan adanya implantasi jaringan endometrium di luar rongga uterus. Endometriosis ditandai dengan terjadinya proses inflamasi kronik di dalam rongga peritoneal, yang menimbulkan berbagai gejala pada penderitanya. Banyak faktor terlibat dalam proses inflamasi kronik endometriosis, salah satunya adalah stres oksidatif. Stres oksidatif pada rongga peritoneal wanita dengan endometriosis salah satunya terkait dengan kondisi iron overload. Hasil artikel review ini menunjukkan bahwa iron overload merupakan salah satu faktor yang berperan dalam perjalanan dan perkembangan lesi endometriosis melalui kemampuannya menginduksi proses inflamasi dan pembentukan molekul radikal bebas. Tujuan artikel review berikut adalah untuk menganalisis dan mengetahui bagaimana peranan iron overload dalam perjalanan penyakit endometriosis, sehingga harapannya dapat menjadi salah satu target pengobatan endometriosis. Metode penelitian yang digunakan yaitu deskriptif kualitatif dengan pengambilan materi berbasis literatur.
\end{abstract}

Kata Kunci : endometriosis, inflamasi kronik, stress oksidatif, iron overload

\section{PENDAHULUAN}

Endometriosis merupakan kondisi ginekologikal yang ditandai dengan adanya implantasi jaringan endometrium di luar rongga uterus. Endometriosis dialami satu dari 10 orang wanita pada usia reproduktif (5\%-10\% wanita usia reproduktif) yaitu kurang lebih 176 juta wanita di dunia (Donnez et.al., 2016; Parasar et.a.l, 2017). Endometriosis cenderung menyerang wanita pada usia berkisar antara 30-40 tahun, namun ternyata data membuktikan bahwa $70 \%$ remaja yang mengalami keluhan nyeri pelvis kemudian akan terdiagnosa dengan endometriosis (Yavuz et.al., 2014). $80 \%$ wanita dengan endometriosis mengalami nyeri pelvik kronik (misalnya dismenorea, dispareunia, non-menstrual pelvic pain dan dyschezia), hanya 20-25\% wanita dengan endometriosis yang tidak mengalami gejala atau asimtomatik, sedangkan 30-50\% wanita dengan endometriosis mengalami infertilitas (Yavuz et.al., 2014; Giliney et.al., 2008; Eisenberg et.al., 2017). Oleh karena itu, endometriosis menjadi sebuah kondisi kronis yang memberikan pengaruh pada kehidupan sehari-hari penderita, hubungan sosial, seksualitas dan juga kesehatan mental wanita dengan endometriosis.

Hingga saat ini, tidak ada pencegahan terkait penyakit endometriosis yang diketahui. Di Negara Amerika Serikat, endometriosis menjadi penyebab utama ketiga rawat inap ginekologi dan dianggap sebagai penyebab primer dan sekunder infertilitas pada perempuan (Parasar et.a.l, 2017). Prevalensi infertilitas yang diakibatkan oleh endometriosis yaitu $0,5 \%$ sampai $5 \%$ pada wanita subur dan $25 \%$ sampai dengan $40 \%$ pada wanita infertile (Parasar et.a.l., 2017). Endometriosis menjadi penyebab utama dilakukannya tindakan histerektomi di Amerika Serikat dengan angka morbiditas yang signifikan terkait tindakan tersebut. 
Etiologi dan proses patogenesis dari kondisi endometriosis belum sepenuhnya diketahui, hal ini berpengaruh pada pendekatan pengobatan dan tindakan medis lain pada kondisi wanita dengan endometriosis. Saat ini, pengobatan yang tersedia untuk kondisi endometriosis adalah tindakan operasi dan pemberian obat (Burney, et.a.l., 2012). Tindakan medikamentosa pada wanita dengan endometriosis dapat berupa Nonsteroidal AntiInflammatory Drugs (NSAIDs) dan obat hormonal, bertujuan untuk mengurangi gejala nyeri, membantu memperlambat pertumbuhan jaringan endometrial dan mencegah pembentukan lokasi adhesi yang baru (Parasar et.a.l., 2017). Namun, pemberian kedua medikamentosa ini tidak dapat menyingkirkan jaringan endometriosis yang sudah ada dan cenderung memberikan efek samping yang buruk terutama untuk penggunaan jangka panjang. Tindakan operasi berupa pengangkatan jaringan endometriosis yang terbentuk bertujuan untuk mengurangi gejala nyeri dan meningkatkan fertilitas, namun dibuktikan bahwa 40-80\% wanita kembali mengalami nyeri setelah dua tahun operasi (Parasar et.a.l., 2017; Eisenberg et al., 2017).

Inflamasi yang bersifat kronik dan berkepanjangan menjadi salah satu mekanisme yang paling khas pada proses patogenesis endometriosis yang menginduksi timbulnya berbagai keluhan dan gejala pada penderita endometriosis sepeti nyeri pelvis kronis hingga infertilitas (Rutherford et al., 2018; Burney et al., 2012; Wu et al., 2017). Inflamasi kronis pada endometriosis berkaitan dengan ekspresi sitokin proinflamasi yang terjadi secara berkepanjangan, diinduksi oleh berbagai stimulus, salah satunya oleh Reactive Oxygen Species (ROS) (Szczepariska et al., 2003). Level ROS pada cairan peritoneal wanita dengan endometriosis lebih tinggi dibandingkan dengan kelompok kontrol, salah satu molekul yang berperan dalam pembentukan ROS adalah iron. Penelitian sebelumnya membutkikan bahwa, pada wanita endometriosis terjadi iron overload di cairan peritoneal dan rongga peritoneumnya (Donnez et al., 2016; Eisenberg et al., 2017). Iron overload memiliki kaitan yang erat dengan proses patogenesis endometriosis, sehingga diharapkan dengan pemahaman mengenai peran iron overload pada patogenesis endometriosis dapat mengarah pada pengobatan yang lebih baik. Selanjutnya, makalah ini akan membahas mengenai peran iron overload pada proses inflamasi endometriosis). Tujuan artikel review berikut adalah untuk menganalisis dan mengetahui bagaimana peranan iron overload dalam perjalanan penyakit endometriosis, sehingga harapannya dapat menjadi salah satu target pengobatan endometriosis.

\section{METODE}

Metode penelitian yang digunakan yaitu deskriptif kualitatif dengan pengambilan materi berbasis literatur.

\section{HASIL DAN PEMBAHASAN Patogenesis Endometriosis}

Mekanisme patogenesis endometriosis belum diketahui secara pasti, namun terdapat beberapa teori terkait dengan proses patogenesis endometriosis, antara lain:

\section{Retrograde menstruation}

Teori ini disebut juga sebagai teori implantasi atau teori Sampson, merupakan teori yang paling lama mengenai patogenesis pada endometriosis. Teori ini menyatakan bahwa, kondisi endometriosis berkembang dikarenakan terjadi refluks jaringan endometrial melalui tuba falopi yang terjadi selama siklus menstruasi berlangsung, jaringan ini kemudian terimplantasi di permukaan peritoneum dan rongga pelvis dan berkembang menjadi lesi endometriosis (Ramos et al., 2012).

Selama proses normal menstruasi, tubuh wanita secara alami akan melepaskan jaringan endometrium. Sel-sel endometrium yang diangkut melalui tuba falopi ke dalam rongga peritoneum saat menstruasi akan merespon terhadap fluktuasi hormonal yang terjadi selama 
siklus menstruasi, sehingga menyebabkan berkembangnya lesi endometriosis. Tidak seperti jaringan endometrium normal yang akan luruh dan secara alami meninggalkan tubuh saat siklus menstruasi berlangsung, implan endometriosis tidak dapat keluar dikarenakan tumbuh di daerah ektopik yang letaknya lebih jauh di dalam rongga pelvis dan perut (Sourial et al., 2016; Seli et $a l .$, 2003). Hal ini kemudian menyebabkan lesi yang sudah terbentuk terus bertumbuh dan berkembang sehingga menyebabkan terjadinya penyebaran lesi endometriosis.

\section{Coelomic metaplasia}

Teori ini diajukan oleh Meyer dan Ivanof pada tahun 1919, dikatakan bahwa endometriosis berkembang dari sel epithelium coleomic yang secara abnormal berdiferensiasi atau bertransformasi menjadi sel endometrial (Sourial et al., 2016). Epitelium coelomic merupakan sel epitel yang melapisi permukaan dinding tubuh dan juga organ perut, merupakan lapisan terluar dari gonad jantan dan betina sehingga juga disebut sebagai germinal epitel Waldeyer (Seli et al., 2003).

Proses metaplasia dari sel epitelial menjadi sel endometrial dapat terjadi dikarenakan berbagai faktor stimulus induktif seperti faktor hormonal dan imunologik yang menstimulasi terjadinya transformasi sel atau jaringan perioteneal normal menjadi seperti jaringan endometrium. Teori ini dinilai lebih sesuai untuk menjelaskan timbulnya endometriosis pada remaja putri di masa pre-pubertas, dan tidak sesuai untuk menjelaskan patogenesis yang terjadi pada wanita usia reproduktif. Teori ini tidak didukung oleh data penelitian eksperimental dan klinis yang cukup.

\section{Teori induksi}

Teori ini dicetuskan oleh Levander dan Normann dan merupakan kelanjutan dari teori coelomic metaplasia. Teori induksi menyatakan bahwa faktor biokimia endogen dan faktor imunologis dapat menginduksi sel yang tidak berdiferensiasi, akan mengalami diferensiasi menjadi jaringan endometrial. Hal ini dibuktikan mellaui percobaan yang dilakukan oleh Levander dan Normann dengan mengimplantasi potongan dinding uterus yang diambil dari kelinci yang hamil ke dalam jaringan subkutaneus kelinci betina berusia dua bulan yang terlebih dahulu distimulasi dengan hormone gonadotropin. Setelah tujuh hari implantasi, hasil observasi menunjukkan bahwa karakteristik sel berubah menyerupai sel endometrium dan terbentuk formasi kista di jaringan sekitarnya Sourial et al., 2016; Seli et al., 2003).

\section{Peran Iron overload pada Inflamasi Endometriosis}

Iron merupakan logam penting untuk semua organisme hidup, namun akumulasi berlebih dalam sel atau jaringan dapat menimbulkan efek toksisitas dan telah dibuktikan bahwa akumulasi iron berlebih berhubungan dengan berbagai macam penyakit, salah satunya adalah endometriosis (Defere et al., 2016). Iron overload turut berperan dalam perkembangan endometriosis dengan mempengaruhi adhesi jaringan endometrial, proliferasi lesi dan angiogenesis (Rocha et al, 2013; Barragan et al, 2016). Penelitian membuktikan bahwa iron overload pada pasien dengan endometriosis diantaranya ditemukan pada cairan peritoneal, jaringan ektopik endometrium dan pada jaringan peritoneum yang berdekatan dengan lesi (Szcepariska et al., 2003; Oeckinghaus et al., 2009).

Kondisi iron overload pada endometriosis terutama berasal dari metabolisme iron oleh makrofag peritoneal yang mengalami peningkatan, hal ini sejalan dengan teori patogenesis yang diajukan oleh Sampson, yaitu retrograde menstruation (Donnez et al., 2016). Peristiwa retrograde menstruation akan membawa eritrosit melalui tuba falopi menuju ke dalam rongga peritoneal, menyebabkan peningkatan jumlah eritrosit pada penderita endometriosis dibandingkan dengan kelompok kontrol. Di lain pihak, pada wanita dengan endometriosis terjadi peningkatan jumlah makrofag teraktivasi di dalam rongga peritoneal yang memiliki fungsi fisiologis untuk degradasi eritrosit. Eritrosit akan didegradasi menjadi hemoglobin yang 
kemudian dipecah menjadi produk antara heme dan iron. Iron dapat disimpan dalam bentuk ferritin, iron transporter transferin (Tf), atau hemosiderin (Defere et al., 2016).

Pada wanita dengan endometriosis, peningkatan iron terjadi di semua bagian rongga peritoneum, hal ini menandakan bahwa homeostasis iron di rongga peritoneal terganggu. Hal ini bisa terjadi diantaranya karena:

1) Kegagalan mekanisme perlindungan sel terhadap akumulasi iron

Sel tubuh memiliki mekanisme perlindungan terhadap kemungkinan terjadinya akumulasi iron yang berlebih, melalui ekspresi Heme Oxygenase ${ }^{-1}\left(\mathrm{HO}^{-1}\right)$ dan protein scavenger lainnya seperti haptoglobin dan hemopexin. $\mathrm{HO}^{-1}$ adalah enzim yang berfungsi dalam proses degradasi heme, aktivasinya akan melindungi sel dari stres oksidatif yang diinduksi oleh heme melalui pembentukan Carbon Monoxide (CO), bilirubin, sintesis ferritin, dan menyingkirkan molekul iron bebas (Morgan et al., 2011). Bilirubin sebagai salah satu produk degradasi heme oleh $\mathrm{HO}^{-1}$ merupakan antioksidan yang penting untuk melindungi sel dari kerusakan oksidatif dan inflamasi (Morgan et al., 2011).

Pada pasien dengan endometriosis, konsentrasi $\mathrm{Hb}$ dalam cairan peritoneal mengalami peningkatan. Namun, $\mathrm{HO}^{-1}$ terekspresi minimal oleh makrofag dan sel mesotelial yang merupakan komponen terbesar penyusun rongga peritoneal (Morgan et al., 2011). Ekspresi enzim $\mathrm{HO}^{-1}$ yang minimal berakibat pada proses degradasi heme-pun minimal, sehingga tidak terjadi peningkatan kadar bilirubin sebagai produk antara. Akibatnya, meskipun tersedia sistem detoksifikasi pada sel tubuh, namun sistem ini tidak mampu memetabolisme $\mathrm{Hb}$ dalam kaitannya dengan kondisi endometriosis (Defere et al., 2016).

2) Kegagalan penyimpanan iron dalam bentuk ferritin

Penyimpanan iron seluler dalam bentuk ferritin akan membatasi kemungkinan iron untuk membentuk free radical species (Donnez et al., 2016). Namun, dalam kondisi endometriosis, terjadi pengiriman iron yang terus-menerus ke makrofag sehingga melewati batas iron yang dapat disimpan dalam bentuk ferritin. Hal ini kemudian menyebabkan akumulasi molekul iron bebas dalam rongga peritoneal yang selanjutnya dapat menginduksi terjadinya kerusakan oksidatif pada sel (Donnez et al., 2016; Defere et al., 2016)

3) Iron terlibat dalam reaksi fenton

Reaksi fenton adalah proses katalisis yang mengonversi hidrogen peroksida menjadi molekul hidroksil yang merupakan produk free radical dan bersifat toksik (Defere et al., 2016). Iron dapat berfungsi sebagai katalisator dalam reaksi Fenton:

$\mathrm{Fe}^{+}+\mathrm{H} 2 \mathrm{O} 2 \rightarrow \mathrm{Fe}^{+}+\mathrm{OH}^{-}+\mathrm{OH}$

Melalui reaksi ini, terbentuk $\mathrm{OH}^{-}$sebagai produk antara reaksi, yang merupakan free radical species. Molekul $\mathrm{OH}^{-}$bersifat sangat reaktif dan mempunyai kemampuan untuk bereaksi dengan berbagai konstituen seluler sehingga dapat menginduksi tejadinya peroksidasi lipid dan menyebabkan kerusakan jaringan (Donnez et al., 2016; Szcepariska et al., 2003).

Berbagai mekanisme yang menyebabkan terjadinya iron overload pada rongga peritoneal, akan menginduksi terbentuknya ROS pada level tinggi sehingga kemudiaan menimbulkan kondisi stres oksidatif (Morgan et al, 2011). Telah dikemukakan sebelumnya, bahwa stres oksidatif menjadi salah satu stimulus yang dapat mengaktivasi faktor transkripsi NF-kB melalui jalur atypical. Aktivasi faktor transkripsi NF-KB akan menginduksi ekspresi sitokin proinflamasi, dan mekanisme ini terjadi terus-menerus.18 Sedangkan di lain pihak, sitokin proinflamasi yang diekspresikan oleh faktor transkripsi NF-kB juga menjadi salah satu stimulus aktivator melalui jalur canonical (Donnez et al., 2016; Morgan et al, 2011). Sehingga siklus aktivasi faktor transkripsi NF-kB dipertahanakan terjadi secara berkelanjutan dalam kasus endometriosis (positive loop) dan berperan dalam timbulnya inflamasi kronis pada endometriosis (Donnez et al., 2016; Morgan et al, 2011). 


\section{Indonesian Journal of Health Science}

Volume 1 No. 2, Desember 2021

\section{PENUTUP}

\section{Simpulan}

Pada wanita dengan endometriosis terjadi berbagai kegagalan dalam mekanisme metabolisme iron serta mekanisme pertahanan endogen yang menyebabkan terganggunya homeostasis iron dalam rongga peritoneal dan berakibat pada timbulnya kondisi iron overload. Kondisi iron overload menginduksi terjadinya peningkatan level ROS dalam lingkungan peritoneal sehingga menginduksi terjadinya stres oksidatif. Stres oksidatif merupakan salah satu stimulus aktivator bagi faktor transkripsi NF-кB. Pada kondisi endometriosis, NF-kB berperan dalam meregulasi ekspresi gen protein terkait kondisi proinflamasi, salah satunya ekspresi mediator proinflamasi. Di lain pihak, sitokin proinflamasi menjadi salah satu stimulus aktivator NF-kB melalui jalur atypical. Dipertahankannya positive loop dalam aktivasi faktor transkripsi NF-KB menyebabkan timbulnya kondisi inflamasi kronis pada penyakit endometriosis.

\section{Saran}

Dengan diketahuinya peranan iron overload pada pathogenesis endometriosis, penelitian selanjutnya dapat dilakukan untuk menganalisis lebih lanjut dampak pengobatan endometriosis yang berfokus pada regulasi atau penekanan kadar iron pada tubuh penderita endometriosis.

\section{DAFTAR PUSTAKA}

Baranov, V., Malysheva, O., Yarmonlinskaya, M., (2018). Pathogenomics of endometriosis development. Int J Mol Sci. 19:1-11.

Barragan, F., Irwin, J.C., Balayan, S., Erikson, D., (2016). Human endometrial fibroblasts derived from mesenchymal progenitors inherit progesterone resistance and acquire an inflammatory phenotype in the endometrial niche in endometriosis. Biol Reprod. 94, 120.

Burney, R.O., and Giudice, L., (2012). Pathogenesis and pathophysiology of endometriosis. NIH Public Access. 98(3).

Defere, S., Ramos, G. R., Louses, J., Colette, S., Donnez, O; Donnez, J, Langendonckt, A. (2011). Insight into iron and nuclear factor kappa B involvement in chronic inflammatory processes in peritoneal enometriosis. Histol Histopathol. 26,1083-1092.

Donnez, J., Binda, M., Donnez, O., Dolmans M-M. (2016). Oxidative Stress in The Pelvic Cavity and Its Role In The Pathogenesis of Endometriosis. Elsevier. 106,1011-1016.

Eisenberg, VH., Weil, C., Chodick, G., Shalev V. (2017). Epidemiology of endometriosis: a large population-based database study from a healthcare provider with 2 million members. BJOG.

Giliney, Me., Oral, B., Karahan, N., Mungan, T. (2008). Regression of Endometrial Explants in A Rat Model of Endometriosis Treated with Melatonin. Elsevier. 89,934-941.

Morgan, M., and Liu Z., (2011). Crosstalk of reactive oxygen species and NF-KB signaling. Nature. 21,103-115.

Oeckinghaus, A., and Ghosh, S., (2009). The NF-кB family of transcription factors and its regulation. Cold Spring Harb Perspect Biol.

Parasar, P., Ozcan, P., Terry K. Endometriosis: epidemiology, diagnosis and clinical management. Curr Obs Gynecol Rep. 6,34-41.

Ramos, G. R., and Defere, S. D. L., (2019). Nuclear factor-kappaB: a main regulator of inflammation and cell survival in endometriosis pathophysiology. Elsevier. 98(3), 520525.

Rocha, A.L., Reis, M.F.., Taylor, R., (2013). Angiogenesis and endometriosis. Obstet Gynecol Int 
Rutherford, E., Hill, A., Hopkins, A., (2018). Adhesion in physiological, benign and malignant proliferative states of the endometrium: microenvironment and the clinical big picture. Cells. 7(43).

Seli, E., Berkkanoglu, M., Arici, A., (2003). Pathogenesis of endometriosis. Elsevier. 30, 4161.

Sourial, S., and Tempest, N.H.D., (2014). Theories on the pathogenesis of endometriosis. Hindawi.

Szczepariska, M., Kozlik, J., Skrzypczak, J., Mikolajczyk M. (2003). Oxidative Stress May Be A Piece In The Endometriosis Puzzle. Elsevier. 79,1288-1293.

Wu, J., Xie, H., Yao, S., Liang, Y., (2017). Macrophage and nerve interaction in endometriosis. J Neuroinflammation. 14(53).

Yavuz, S., Aydin, N., Celik, O., Yilmaz, E., Ozerol, E., Tanbek K. (2014). Resveratrol Successfully Treats Experimental Endometriosis Through Modulation of Oxidative Stress and Lipid Peroxidation. J Cancer Res Ther. 10(2),324-329. 